\title{
Profitability of Agricultural Research: The Case of Genetic Improvement of Cattle for Milk Production in Cameroon.
}

\author{
D.P. Pingpoh ${ }^{1}$, D.A. Mbah' ${ }^{2}$ L.C. Tawah ${ }^{1}$ \\ ${ }^{1}$ C.R.Z.V., Wakwa, B.P, 65 Ngaaudare, Adamaara Proince, Cameroon \\ ${ }^{2}$ Dept. of Valorisation and Dexdopment Support, Ministry of Säntific and Technical Resererch B.P. 1457, \\ Yaaunde, Cameroon,
}

The First version of this article was presented at the National Research Week (1997) proceedings of which have not been published. Hence, this updated version iams to put the information at the disposal of policy makers and developers.

${ }^{*}$ Corresponding author, E-mail: dambah@yahoocauk

\begin{abstract}
D ata from production and financial records from the Wakwa Centre for Animal and Veterinary Research were used to find out whether or not genetic improvement for dairy production is a profitable investment. The herd projection computer program was used to herd-project the performance of 100 Holstein $\mathrm{x}$ Gudali crossbred and 100 Gudali heifers over a 10-year period. Despite the high mortality rate of the crosses, their overall improvement over the local Gudali led to a benefit-cost ratio of 4.21. This suggests that genetic improvement of local cattle through crossbreeding for dairy production can be a profitable venture. Crossbred dairy farming is therefore recommended for the dairy industry in Cameroon.
\end{abstract}

Keywords. Cattle, genetic improvement, milk production, profitability, Cameroon.

\section{Résumé}

D es données extraites des archives de production et des finances du Centre de Recherche Zootechnique et Vétérinaire de Wakwa ont été utilisées pour vérifier si l'amélioration génétique de la production laitière constituait un investissement rentable ou pas. Le programme informatique pour la projection de la performance du troupeau était utilisé pour projeter la performance de 100 génisses croises Holstein $\mathrm{x}$ Gudali et 100 génisses Gudali pendant une période de 10 ans. Malgré le taux éleve de la mortalité des croises leur amélioration dans l'ensemble par rapport aux Gudali locaux a donné lieu à un rapport de bénéfice-cout de l'ordre de 4,21. Ce qui suppose que l'amélioration génétique par croisement du bétail local aux Holsteins exotiques pour la production laitière est une entreprise rentable. La production laitiere par le croisement du betail est ainsi recommende pour le Cameroun.

Mots clés. Bovins, amélioration génétique, production laitière, rentabilité, Cameroun.

Received:_12_/_02_/ 2019

Accepted:_02_/_04_/ 2019

DOI: https:// dx.doi.org/ 10.4314/ jcas.v15i1.1

(c) TheAuthors This work is licensed under theCreativeCammons Attribution 4.0 Intemational Licene 


\section{INTRODUCTION}

Cameroon spends huge amounts of scarce foreign currency to import massive quantities of milk and dairy products annually to satisfy domestic demand. For example, during the period 1986 to 1991, imports were about 8,513 tonnes of milk and 3,248 tonnes of dairy products and resulted in the total annual expenditure of about 10 billion FCFA (before the 50\% devaluation of 1994). Aware of this dairy deficit, the country embarked on different strategies to improve the situation since 1968 (Munji, 1973, Lhoste and Pierson, 1974, Tchoumboue and Jousset, 1982). In this regard, Munji (1973) and Lhoste and Pierson (1976) demonstrated that local breeds were genetically inadequate for dairy production.

The Adamawa and Northwest Regions of Cameroon have been shown to have favourable conditions for the development of an indigenous dairy industry based on crossbred dairy cattle. The Government of Cameroon established research stations in these two regions to research into the improvement of the dairy potential of local breeds. However, this profitability study was focused on the information accumulated over the years at the Wakwa Animal and Veterinary Research Centre.

G eographically, most of the Adamawa region lies between 900 and 1500 meters above sea level with approximately $1600 \mathrm{~mm}$ rainfall per annum. The dry season is relatively short, 3-5 months (November/ December-March), and a rainy season of 7-9 months (March/ April-November). The vegetation is dominated by woody savannah interspersed with zones of mixed shrubs and trees. Temperatures are moderate (average 22oC) with little variations within the year.

Because of this potential, the governments of Cameroon (through the Institute of Animal Research (IRZ)) and France (through Institut d'Elevage et Medecine Veterenaire des Pays Trupicaux (IEMVT)) entered into a co-operative effort in 1969 to experiment on artificial insemination in Wakwa using imported frozen dairy semen on local Gudali cows aimed at dairy production improvement.

With the arrival of Heifer Project International (HPI) in 1974 (Goldman and Talbot, 1984) dairy research activities were intensified. Goldman et al. (1985) indicated that modification of traditional husbandry practices can be profitable. Biologically, dairy results indicate improvement by crossbreds of 3-4 times (milk yield) over local cattle (Mbah et al, 1987). Figure 1 presents a Gudali cow and a crossbred Hostein-Gudali F1 cow.
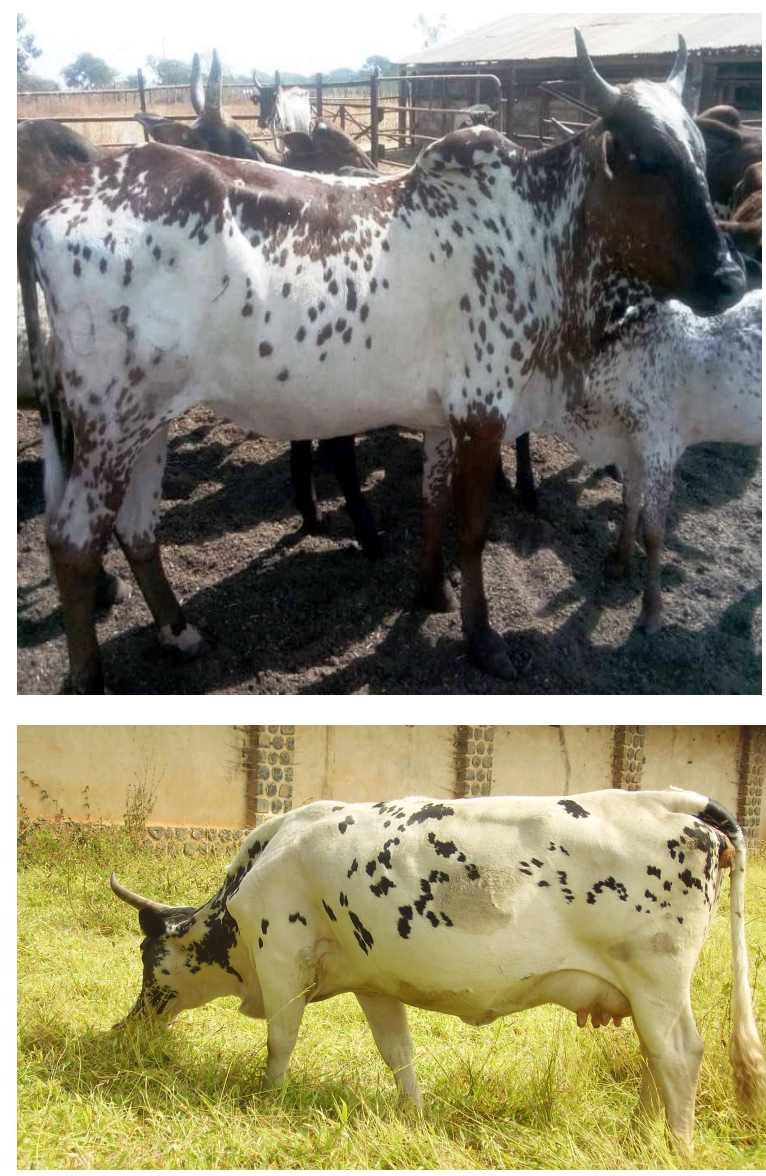

Figure 1: Gudali cow (CRAW) and Crossbred Holstein Gudali cow $\{$ TDC $\}$

The question that needs to be answered is whether or not genetic improvement of cattle for milk production is a profitable investment (i. e. inputs of financial, infrastructural and human resources required). This paper seeks to answer this question 
by analysing data accumulated over the years at the Wakwa Animal and Veterinary Research Center (IRZ).

\section{MATERIALS AND METHODS}

Data for this study were collected from IRZ Wakwa Center's production and financial records on Gudali and Holstein x Gudali crosses. Mbah et al. (1987) reported calving rates of at least $79 \%$, age at first calving of 811 (27 months) to 927 (31 months) days and mortality rates of 7 to $12 \%$ (birth to 36 months) for crosses with mean lactation milk yield $(\mathrm{kg})$ ranging from $1551 \pm 899$ (Holstein x Red Fulani) to $1574 \pm 895$ (Holstein $\mathrm{x}$ Gudali) at Bambui and Wakwa, respectively. The study used the lower calving rates and higher mortality rates (Table 1) in arriving at conservative estimates of benefit-cost ratio.

Using the herd projection computer program (HEPRO) and the conservative production parameters of the improved and unimproved animals (Table 1), 100 heifers each from the improved (Holsetein x Gudali F1) and local Gudali animals, all assumed produced on the station, were herd-projected for 10 years. Maximum numbers of animals to reach in each year were 100. This implies that surplus animals after necessary replacements were culled and sold. The variable costs considered for each animal category were forage, feeds, veterinary drugs, labour, and materials (including semen for the artificially inseminated animals). Fixed items such as buildings, paddocks, crush, etc, were assumed equally used by the two groups of animals under study. Therefore, fixed costs were not included in the calculations. The incremental variable costs of the improved animals were used for this analysis (i.e. the increases in variable costs of improved animals compared with the local Gudali). The benefits of each animal genotype were derived principally from milk and the byproducts of a dairy herd operation such as culled heifers and cows, culled mature bulls (for
Gudali), culled and surplus heifers, and surplus young bulls.

The incremental benefits of the improved animals were used in the analysis (i.e. the increases in the above outputs of improved animals compared with the Gudali). For the benefit and cost valuations, constant prices were used rather than current prices assuming inflation will affect the prices of costs and benefits equally. This allowed the authors to avoid making risky estimates of future inflation. Farm gate prices were assumed and no marketing costs were considered in the analysis. The discount factor (i.e. the rate at which the enterprise is able to borrow money) was $10 \%$ in this case. This reflected the actual borrowing interest rate of the commercial banks at the time of the study.

\section{RESULLTS AN D DISCUSSION}

Table 1 shows that with the conservative approach adopted, the mortality (20\%) for crossbreds is 5 times that of the Gudali (4\%) although Mbah et al (1987) had reported three times (11.8\% versus $4.3 \%)$.

The variable costs per crossbred animal per year is above six times that of the Gudali. However, milk production combined with the reproductive efficiency and growth reinforces the apparent advantage of the crossbreds over the purebred local cattle (Gudali).

Table 2 shows the benefit-cost analysis of improved dairy animals compared to the Gudali cattle in Wakwa. The incremental benefit-cost ratio of improved dairy animals, at 10\% discount rate, is 4.21. This means that if costs were to rise four times in 10 years, the improved dairy animals will still be more profitable compared to the local Gudali cattle. The Net Present Value (NPV), which is simply the present worth of the incremental net benefit, is 59,241,106 FCFA. 


$\begin{array}{lll}\text { Production Parameter } & \text { Gudali } & \text { Crossbred Animal* } \\ \text { Initial number or heifers, 3-4 yrs } & 100 & 100 \\ \text { Calving rate of cows, \% } & 56 & 56 \\ \text { M ortality rates \% } & & \\ \text { Female calves } & 4 & 20 \\ \quad \text { Males calves } & 4 & 20 \\ \text { 1-2 year old cattle } & 4 & 20 \\ \text { 2-3 year old cattle } & 4 & 14 \\ \text { 3 year old cattle } & 4 & 14 \\ \text { Calving rate of heifers, \% } & 75 & 75 \\ \text { Fertility rate of heifers, \% } & 73 & 80 \\ \text { Productive lifetime of cows, years } & 6 & 6 \\ \text { First calving age, years } & 3.5 & 3 \\ \text { Culling age of steers, years } & 4 & 2 \\ \text { Max. Number of cows to reach } & 100 & 100 \\ \text { Reduct. Mort. Rate fem. Calves \% } & 0 & 5 \\ \text { Reduct. Mort. Rate male calves, \% } & 0 & 5 \\ \text { Values of cattle per head, F CFA } & & \\ \quad \text { 1-2 year old heifer } & 56000 & 57750 \\ \text { 2-3 year old heifer } & 80150 & - \\ \text { 1-2 year old steer } & 56000 & 57750 \\ \text { 2-3 year old steer } & 80150 & - \\ \text { Milk produced per cow, peryear, kg } & 500 & 1800 \\ \text { Price obtained per kg milk, FCFA } & 200 & 200 \\ \text { Variable costs per cow and year, FCFA } & 11300 & 70615 \\ \text { Years of projection } & 10 & 10 \\ & & \end{array}$

Hostein x Gudali F1; calving and mortality rates for crosses are conservative estimates Compared to those of Mbah et al. 1987.

Table 2: $D$ airy ben efit-cost analysis of crossbred versus local cattle in Wakwa, Cameroon*

\begin{tabular}{|c|c|c|c|c|c|c|c|}
\hline Year & $\begin{array}{l}\text { Incremental } \\
\text { Cross Costs } \\
\text { (F cfa }\end{array}$ & $\begin{array}{c}\text { Discount } \\
\text { Factor } \\
10 \%\end{array}$ & $\begin{array}{c}\text { Present } \\
\text { W orth Costs } \\
10 \%\end{array}$ & $\begin{array}{c}\text { Incremental } \\
\text { G ross } \\
\text { Benefit } \\
\text { (Fcfa) }\end{array}$ & $\begin{array}{c}\text { Discount } \\
\text { Factor } \\
10 \%\end{array}$ & $\begin{array}{l}\text { Present W orth } \\
\text { Benefit } \\
(10 \%)\end{array}$ & $\begin{array}{l}\text { Undiscounted } \\
\text { Net Benefit } \\
\text { (Fcfa) }\end{array}$ \\
\hline 0 & 0 & 0.909 & 0.000 & 612,500 & 0.909 & $556,762.500$ & 612,500 \\
\hline 1 & $4,448,625$ & 0.826 & $3,674,564.250$ & $18,734,275$ & 0.826 & $15,474,511.150$ & $14,285,650$ \\
\hline 2 & $3,707,188$ & 0.751 & $2,784,095.188$ & $15,611,979$ & 0.751 & $11,724,596.229$ & $11,904,791$ \\
\hline 3 & $3,089,323$ & 0.683 & $2,110,007.609$ & $13,544,463$ & 0.683 & $9,250,868.229$ & $10,455,140$ \\
\hline 4 & $3,740,431$ & 0.621 & $2,322,807.651$ & $15,762,170$ & 0.621 & $9,788,307.570$ & $12,021,739$ \\
\hline 5 & $3,329,948$ & 0.564 & $1,913,622.672$ & $13,718,307$ & 0.564 & $7,737,125.148$ & $10,325,359$ \\
\hline 6 & $3,155,736$ & 0.513 & $1,618,892.568$ & $12,621,026$ & 0.513 & $6,474,586.338$ & $9,465,290$ \\
\hline 7 & $3,160,051$ & 0.467 & $1,475,743.817$ & $13,635,159$ & 0.467 & $6,367,619.253$ & $10,475,108$ \\
\hline 8 & $3,100,939$ & 0.424 & $1,314,798.136$ & $11,892,544$ & 0.424 & $5,042,438.656$ & $8,791,605$ \\
\hline 9 & $3,246,889$ & 0.386 & $1,243,299.154$ & $13,710,170$ & 0.386 & $5,292,125.620$ & $10,463,281$ \\
\hline T otal & $31,042,130$ & & $18,468,834.045$ & & & $77,708,940.693$ & $98,800,463$ \\
\hline
\end{tabular}

$\begin{array}{lll}* \text { BENEFIT/ COST RATIO AT 10\% DISCOUNT RATE } & = & 4.208 \\ \text { NET PRESENT VALUE AT 10\% DISCOUNT RATE } & = & 95,241,106,648 \mathrm{FCFA}\end{array}$


Since resources (human, financial and materials) are scarce in Cameroon, as in most developing countries, they need to be allocated in such a way that benefits are maximized for a given cost. As has been shown by this study, genetic improvement of livestock for dairy production is one such strategy. More recent information coming from the farm/ business level (Tadu D airy Cooperative [TDC] which adopted crossbreeding since 1990, Ntungwe, 2017) supports this conclusion. In fact, Ntungwe (2017) reported that between 2010 and 2015, "milk production substantially increased from 48,000 tonnes to 184,000 tonnes because of the Tadu project". These figures were earlier reported by Bayemi et al. (2005). It is important to note that the Ministry of Livestock, Fisheries and Animal Industries (MINEPIA) had earlier adopted genetic, breeding and management programmes for its Smallholder Dairy D evelopment Project (Mbah, 2008).

\section{CONCLUSION AND RECOMMENDATION}

This study shows that using conservative estimates of reproduction and mortality figures for both local and crossbred animals' dairy production through crossbreeding of local cattle in Cameroon can be a profitable investment. It is also important to note that improved environmental conditions such as improved feeding and healthcare and sound management and adequate housing of the crosses could further improve the profitability of this enterprise. This is seen in the case of the TADU Dairy Project. Crossbred dairy farming is therefore recommended for those interested in the dairy industry in Cameroon, especially considering the high milk and dairy productions consumption in the country.

\section{ACKN OWLEDGEMENTS}

The authors thank all the technicians in the beef/ dairy sections for their part in data collection.
They thank the Director of the Institute of Animal and Veterinary Research for authorizing the publication of the data.

\section{REFERENCES}

Bayemi P. H., Bryant M. J., Perera M. A. O., Mbanya J.N., and Cavestany (2005) Milk Production in Cameroon: A Review. Livestock Research for Rural Development 17(6): 1 - 20

Goldman, M. and Talbott, C. (1984) Comparison of the performance of exotic and crossbred dairy cattle under small holder conditions in the North West Province, Cameroon, 1980-eliminary Analysis. Heifer Project International, Bamenda Institute of Animal Research, Bambui Centre.

Goldman, M., Vabi, V. and Mbah, D.A. (1985) Semi-intensive commercial dairy farming in the Adamawa Province, Republic of Cameroon: A case study. Rev. Sco. Et Tech. Ser. Sci. Zootech. 1 (4): 71-78.

Lhoste P. and PiersonJ. (1974) Annual report, CRZ, Wakwa

L'hosteza P. and Pierson J. (1976) Annual report, CRZ, Wakwa.

MINEPIA, (2008) Genetic, Breeding and Management Programmes:The Smallholder D airy Development Project: Northwest and Adamaoua Components. Report prepared by D. A. Mbah.

Mbah, D.A., J. Mbanya and O. Messine (1987) Performance of Holsteins, Jerseys and their zebu crosses in Cameroon: Preliminary results. Rev. Sci. et Tech. Ser. Sci. Agron. Et Zootech. 3(2): 115-126. 
Munji M.T. (1973) Annual report, ARC, Bambui. Ntungwe E.(2017) Milk : An entrepreneurial approach to dairy transformation. http:/ / spore.cta.int/ en/ business/ an.entrepreneurialapproach-to-dairy-transformation.html

Rapport Annuel( 1969) Tome 1: Zootechniques, IRZ Wakwa. Pp. 66-74.

Tchoumboue J. and Joussert M.M.(1982) Essai d'acclimatisation des vaches laitieres de la race Brune des Alpes a la ferme experimentale de $l^{\prime} E$ cole National Superieure Agronomique a Nkolbisson (Cameroun). Rev. Sci. Tech. 2(2-3) : 107-115. 